University of Michigan Law School

University of Michigan Law School Scholarship Repository

\title{
A "Humanitarian" Approach to Individual Injury
}

Christina B. Whitman

University of Michigan Law School, cwhitman@umich.edu

Available at: https://repository.law.umich.edu/reviews/44

Follow this and additional works at: https://repository.law.umich.edu/reviews

Part of the Law and Society Commons, and the Torts Commons

\section{Recommended Citation}

Whitman, Christina B. "A 'Humanitarian' Approach to Individual Injury." Review of The Duty to Act, by M. Shapo, and A Nation of Guinea Pigs, by M. Shapo. Mich. L. Rev. 79 (1981): 762-73.

This Review is brought to you for free and open access by the Faculty Scholarship at University of Michigan Law School Scholarship Repository. It has been accepted for inclusion in Reviews by an authorized administrator of University of Michigan Law School Scholarship Repository. For more information, please contact mlaw.repository@umich.edu. 


\title{
A "HUMANITARIAN" APPROACH TO INDIVIDUAL INJURY
}

\author{
Christina B. Whitman*
}

The Duty To Act: Tort Law, Power \& Public Policy. By Marshall Shapo. Austin: University of Texas Press. 1977. Pp. xxi, 203. \$11.95.

A Nation of Guinea Pigs: The Unknown Risks of ChemlCal Technology. By Marshall Shapo. New York: The Free Press. 1979. Pp. xvi, 300. $\$ 12.95$.

Individual injury law was once an important arena for the definition of shared values. It has increasingly become the domain of various species of systems analysts who measure legal results against external norms defined by such disciplines as economics. Although legal scholars continue to use the expectations and beliefs of ordinary men and women in fashioning rules for the redress of constitutional injuries, common-law scholars have become less willing to ground legal principles in moral consensus. There are notable exceptions. ${ }^{1}$ Among these is Professor Marshall Shapo, who, in two recent works, attempts to develop a legal analysis of injury that "requires a substantial component of moral judgment" (Duty, p. xiii), "an analysis centered on humanitarian elements and considerations of fairness" (Duty, p. xv).

Professor Shapo's search for a moral content to law leads him to conclude that power and dependence are the sources of legal obligation. From this conclusion Shapo constructs a model which, he suggests, can support an analysis of injury law in general. In $A$ Nation of Guinea Pigs, Shapo looks primarily at questions of administrative law. He argues that those with the power to control scientific enterprises should exercise that power to avoid any risk of injury to the unsuspecting citizens who rely on their expertise. In The Duty To $A c t$, Shapo turns to the tort law question of the scope of the duty to render aid, and proposes that the law adopt a greatly expanded the-

* Associate Professor of Law, University of Michigan. B.A. 1968, M.A. 1970, J.D. 1974, University of Michigan. - Ed.

1. The most prominent of these can be found in R. EPSTEIN, A THEORY OF STRICT LIABILITY (1980), and Fletcher, Fairness and Utility in Tort Theory, 85 HARv. L. REv. 537 (1972). 
ory of the obligation to act. ${ }^{2}$

Shapo's thesis is that a moral consensus supports the use of power to preserve individual life. He infers this consensus, in part, from the expectations expressed by people involved in certain power-dependent relationships. Those in power have a duty to respond to these expectations, says Shapo, because their power is derived from "social nourishment" (Duty, p. 3). A significant contribution of Shapo's analysis is his insistence that power and dependence cannot be understood without attention to psychological realities such as images of authority and emotions of helplessness and dependence. This is an important, if not wholly novel, insight into injury law. In such emotions Shapo finds further evidence of a moral consensus that power should preserve individual life. He then attempts to explain how law should implement this consensus.

This is an admirable effort. However, it ultimately fails, for two reasons: Shapo does not persuade the reader that this moral consensus is widely shared on more than a very abstract level; and he does not translate his perceptions about emotions and images - his perceived moral consensus - into sufficiently precise guides for decision making. These have been recurrent problems for those who wish to build tort models on moral principles. It has proved to be extremely difficult to define shared values in terms broad enough to support an argument from consensus, yet sufficiently specific to be adopted and applied by judges. ${ }^{3}$ In both books, Shapo devotes most of his attention to the first task, defining a consensus, and makes only peripheral suggestions for rules of decision.

\section{The Duty To Act begins with the}

working principle that one has a duty to aid others in situations in which hazardous conditions necessitate assistance for the preservation

2. The duty to render aid has been defined narrowly by the common law. Although those who choose to act have an obligation to act reasonably, there is no general duty to choose to act for the benefit of another even when the failure to act is unreasonable. See, e.g., Union Pac. Ry. Co. v. Cappier, 66 Kan. 649, 72 P. 281 (1903); Buch v. Amory Mfg. Co., 69 N.H. 257, 44 A. 809 (1897). Exceptions are made in certain defined situations where a duty to volunteer aid is imposed - for example, when there is a pre-existing relationship between the defendant and the injurer or the plaintiff, see, e.g., Tarasoff v. Regents of the Univ. of Cal., $17 \mathrm{Cal} .3 \mathrm{~d}$ 425, 131 Cal. Rptr. 14, 551 P.2d 334 (1976); Middleton v. Whitridge, 213 N.Y. 499, 108 N.E. 192 (1915); or when the defendant has undertaken to aid the plaintiff and has been derelict in carrying out that task. Union Pac. Ry. Co. v. Cappier, 66 Kan. 649, 72 P. 281 (1903).

3. A model designed to influence as well as to explain results must be sufficiently precise to contribute to the principled resolution of individual cases, and yet sufficiently flexible to be incorporated into existing structures by judges who are trained to decide limited questions with reference to precedent. Richard Epstein, for example, has developed a precise and useful normative theory, but its adoption would require major changes in language, analysis, and procedure of the sort that only the most courageous and confident of common-law judges would make. 
of life and of physical integrity [as well as other personal interests], and in which one possesses the power to expend energy in that task without serious inconvenience or possibility of harm to himself. [Duty, p. 69.]

In other words, those whom society has allowed to retain power have a legally enforceable obligation to use that power to aid and protect others.

The book consists entirely of the repeated application of this "working principle" to situations in which a person or institution might be required to protect others from hazards not of its own creation. Shapo applies his principle initially to economic relationships, such as those between employer and employee, and businessman and customer. He extends it beyond situations with contractual "overtones" to include dependencies that arise solely because of emergency. Finally, Shapo argues that modern man's increased reliance on government creates a public obligation to exercise the considerable power of nation, city, and state to come to the aid of citizens. He begins his argument for government obligation with the relatively simple case of aid to travellers on public highways and extends it to the provision of services such as police and fire protection. He concludes by arguing that legislators, if not judges, should recognize an obligation to provide welfare services to victims of trauma and other dependent people.

Shapo's model purports to be all-encompassing. He does not reject the insights of welfare economics, but he finds them of use only when they support the perceptions of "justice" that he finds compelling. Humanity, he argues, "refuses to balance nicely" (Nation, p. 90).

Unfortunately, Shapo's refusal to "balance nicely" leaves his model imprecise and unhelpful. The social consensus that Shapo discerns - in A Nation of Guinea Pigs, as well as The Duty To Act puts ultimate value on the preservation of individual life, and requires that those who have the power to preserve life should exercise that power. This principle is attractive in the abstract. But Shapo does not explain how to apply it in practice - how to determine in which cases to impose a duty to render aid. A key problem lies in deciding who has power and who is dependent. Although Shapo describes the sorts of expectations that are to be the bases of legally enforceable obligations, his description is vague and elusive. For example, he appeals to "a representational background of aid and succor" (Duty, p. 21), or an "aura of reliability" (Duty, p. 31). Reliance is apparently relevant, but in describing the role that it should play in decision making, Shapo gives little guidance other than: "The de- 
pendence created by reliance on an established commercial enterprise, or by the employment relation, embodies a moral content that properly may influence judicial decision" (Duty, p. 50).

Finally, Shapo acknowledges factors that cut against his "working principle," but again only in a very abstract fashion. The following summary of his analysis exemplifies his language and tone:

Generally, I shall suggest here that it is well to begin the analysis of such personal injury cases by discovering where the locus of power lies and estimating the consequences of that social geography. One should then proceed to examination of the overlapping conceptualisms and realities of fortuity, culpability, and choice, as well as the social infrastructure of ethical concern, which produce results in individual cases that reflect the complex relationships these factors bear among themselves and with the facts of power. [Duty, p. xx.]

I suspect that judges may find this model difficult to understand and apply.

I do not mean to suggest that the book does not discuss specifics. Indeed, the bulk of the volume consists of a series of cases that illustrate specific power-dependence relationships. But there is no middle ground between case and theory. The cases serve merely to illustrate abstractly stated principles, and do not yield particular legal rules for the resolution of future cases.

Of course we value individual life. The problem is that Shapo argues for the easiest case. If asked, "Should you throw a rope to a drowning man?" or "Should the government protect the public from criminals?" the man-on-the-street would answer "Yes." The hard question is not whether we value individual life, but why we do not uniformly effectuate that value in our laws and regulations. The common law does not always, or even usually, require that a rope be thrown to a drowning man. The government seldom compensates victims of crime for their injuries even when there has been a default of police protection. It is not sufficient to say, as Shapo does, that these results are inconsistent with our belief that life is of ultimate value. He must address a question that he evades by failing to articulate concrete rules: Why have we accepted departures from our general desire to promote the preservation of human life? Are the arguments for these departures wrong?

Another reviewer of The Duty To Act has suggested that a general duty to come to the aid of another has not been imposed by the common law for methodological reasons: the formal rule that there is no duty to act except in certain easily defined cases is more efficient in the long run than an ad hoc consideration under negligence 
principles of the costs and benefits of action in each case. ${ }^{4}$ This analysis, though insightful and persuasive as an explanation of the common law, is not precisely responsive to Professor Shapo. Shapo is not advocating an ad hoc analysis based on efficiency or any other principle. Much of what he says can be read as an argument for an alternative formal rule based on the ownership of power. Unfortunately, because he is not precise in formulating guides for decision in specific cases, Shapo leaves the impression that case-by-case decision making will be the norm under his model. Indeed, as he describes it, the power-dependence model appears to be even more cumbersome than negligence analysis, for it must account for emotions and expectations as well as more easily defined costs and benefits.

A greater problem is whether the consensus that Shapo purports to discern even exists. That we are willing to discuss methodology in this context suggests that we are willing to accept some loss of life in the interests of ease of decision making. Or, at least, it suggests that the preservation of life is not the only consideration that enters into the formulation of legal rules.

By focusing on what potential beneficiaries expect from those who hold power, Professor Shapo has biased his reading of community mores. As individuals we may greatly respect the value of our own lives, but we do not always agree that the preservation of other undefined lives is worth even relatively trivial sacrifices on our part. In other words, there is a difference between what we expect for ourselves and what we expect to do for others.

Individuals are most likely to generalize from the rights they demand for themselves to the responsibilities that they owe to others in a strongly cohesive society. Indeed, the argument made in The Duty To Act assumes a society of extraordinary cohesion, composed of a web of relationships so clearly defined that they can be the source of legal obligations. These obligations, in Shapo's view, arise in even the most transitory or ambiguous relationships. For example, in arguing that a cab driver owes a duty to his passenger to obtain identifying information when another driver causes an accident, Shapo refers not to contract, but to "a community sense of what is fair in the psychological context of trust and dependence involved" (Duty, p. 19). Similarly, the obligation of one partner in an illicit affair to save the other from an overdose of drugs "depends significantly on the moral sense of the community" "that helplessness impose[s] an obligation" (Duty, p. 42). But we may wonder whether our society is

4. See Powers, Book Review, 57 Texas L. Rev. 523, 527-28 (1979). 
as cohesive - and these relationships as well defined - as Shapo would have us believe.

Perhaps inevitably, Professor Shapo's efforts to derive a community consensus from the expectations of potential beneficiaries are vague and impressionistic. For example, his argument that a hotel owner has a duty, redressable in tort, to protect a hotel guest from robbery and threat of rape proceeds as follows:

The room payment is the most obviously identifiable fuel of his duty, but the obligation also arises from psychological bases related to the circumstances of hotel keeping. Strong, if implicit in the background of this decision, is the image of the weary traveler who wants to let down his defenses and who assumes that corridors and rooms are secure. [Duty, p. 43.]

Good arguments exist, I believe, for imposing many of the obligations that Shapo advocates (including those described above), but these arguments are not easily derived from a broad appeal to consensus. In numerous instances the appeal to obligation derived from power evades clear description in terms of rules that would support decision:

[A]n entrustment factor intrudes into the psychological background. [Duty, p. 18.]

At this juncture default in maneuvering ties back into the planning function and becomes enwrapped in it, accenting the origin of a duty that arises from the ability to deliberate and choose. [Duty, p. 49.]

One reason why it is difficult to translate consensus into rules is that the consensus is unstable. Another reason is that legal rules do more than evaluate the morality of action or inaction. Tort litigation requires us to ask not only, "Was the defendant's act wrong?" but also "Does the plaintiff have a right to defendant's money?" In The Duty To Act, Shapo addresses society's view of moral obligation; he pays less attention to the fact that tort law provides a monetary remedy. When the defendant's wrongful conduct consists of failure to aid the plaintiff - say, failure to provide police protection, medical care, or sound education - the moral question is often easier than the question of compensation. We may feel, for instance, that the government should provide police protection in a public housing project, but is it so clear that tort law should require the public to compensate victims of crime?

The transfer of money from one party to another through tort litigation is not the most promising vehicle for expression of public morals. On the one hand, draining public or private funds is often too serious a sanction for breach of duty, particularly when there are 
many competing obligations. ${ }^{5}$ On the other hand, compensation of seriously injured people is often too important to hinge it on moral responsibility. ${ }^{6}$ It is no accident that the elucidation of value through law now takes place primarily in other areas. For example, both constitutional law and administrative law have advantages over tort law for courts seeking to shape public morals. Courts deciding constitutional questions may grant remedies other than damages, ${ }^{7}$ and may limit inquiry to the principles essential to the American vision of society. Administrative law offers options for informationgathering and the drafting of remedies that are often more varied and flexible than those available to courts applying the common law.

In his second book, $A$ Nation of Guinea Pigs, Professor Shapo shifts his attention to questions of administrative law. Nation is superficially quite different from Duty. The second book undertakes "to develop principles for the regulation of scientific progress" ( $\mathrm{Na}$ tion, p. 1). Professor Shapo's primary concern is the legal response to scientific advances that entail uncertain, long-term risks. Because scientific knowledge is often limited and incomplete, it is inevitable that some dangers will appear only after widespread and long-term public exposure - a process Shapo calls "market experimentation" on public "guinea pigs." The ties to the analysis of The Duty To Act should be apparent. Nation is, in effect, an application of the powerdependence model. Where Duty argues that the powerful have a duty to render aid to the dependent, Nation argues that the powerful - those in control of scientific enterprises - must avoid subjecting the public to the risks of those enterprises.

Nation begins by discussing "what science is" (Nation, p. 1). Shapo's purpose in explaining science to nonscientists is not to make regulators more sympathetic to scientific values. Quite the contrary. Professor Shapo's goal is to demonstrate - and he does this quite persuasively - that the exercise of judgment plays as large a role in science as it does in law. The accumulation of data by scientists cannot help us decide whether to incur imperfectly understood risks. By definition, persuasive data is not available. Decision must turn, instead, on judgment and morality. Therefore, Shapo argues, deference to science, and even the law's traditional insistence that hard

5. See Whitman, Constitutional Torts, 79 MrCH. L. Rev. 5 (1980).

6. See generally J. O'Connell, The Lawsuit LotTery: ONLY the Lawyers Win (1979).

7. See Whitman, supra note 5, at 41-62, for a discussion of situations in which injunctions or declaratory judgments may be preferable to damage awards as a response to constitutional wrongs. 
evidence be proffered to justify government intervention, are inappropriate when there is even a hint of serious risk. The question, then, is what standard for intervention should replace deference to science.

Like The Duty To Act, Nation asserts the existence of a moral consensus to sacrifice other values for the preservation of individual life. Here, too, Shapo argues through a series of ad hoc examples, trying to demonstrate a social consensus not to incur unknowable "manmade" risks. The strongest of these examples is the passage of the Delaney Amendment, ${ }^{8}$ which represents "a legislative decision to avoid substances with cancer-causing propensities even at great cost" (Nation, p. 142). But again, Shapo fails to convince us either that such a consensus exists or that it can serve as a concrete guide to decision.

The argument from consensus is even harder to make in Nation. The Duty To Act assumed a cohesive society. That we do not live in such a society is one of the premises of Nation. In the earlier book, Shapo focused exclusively on the expectations of the potential beneficiaries of the exercise of power. In Nation, Shapo's effort to understand the scientific point of view leads him to look also at the expectations and assumptions of those in control of scientific enterprises. Unsurprisingly, those expectations differ from the consensus Shapo discerns in the wider society. In consequence, he argues we should distrust the exercise of power by scientists, industry, and even by consumers who may choose to further their own short-term profit while incurring undefined long-term risks to other, perhaps unborn, individuals.

Shapo argues not only that deference to scientific judgment is unjustified, but also that "market experimentation" is wrong unless the affected individuals consent. However, express consent to exposure to a particular hazard will not often be forthcoming or obtainable. Consumers may lack the information or the expertise fully to understand the options, and scientists, because of their own limited knowledge, may be unable fully to inform them. When consent is unavailable, Shapo advocates an extremely risk-averse approach. His "working principle" in this book is that "a responsibly hypothesized possibility that an experiment [e.g., a product, or the side-effects of technological development] will cause any type of long-

8. 21 U.S.C. $\$ 348$ (c)(3)(A) (1976). In essence, the clause provides that not the slightest amount of an additive is to be tolerated in food if that additive has been found to cause cancer in man or animal. This ban applies even if the findings of cancer are based on the experimental use of very large amounts of the substance. 
lasting personal harm should be grounds for prohibiti[on]" in the absence of clear consent (Nation, p. 45).

The role of law, says Shapo, is to "mediate among" scientists and the public (Nation, p. 21), and thereby ensure that scientists understand and implement this "working principle." But the hard question is not whether scientists and the public should communicate. That seems obvious. The question is, rather, whether they can communicate. Shapo asserts that law should "cut through impressions of expertise to gain dispassionate analysis" (Nation, p. 20). That helps little, for what we need to know is whether and how the public, or lawyers as its representatives, can think dispassionately about the risks inherent in progress. Can anyone understand the problem without expertise? Can expertise be acquired without introducing bias? Shapo urges lawyers to be skeptical. But he does not tell us how lawyers and regulators can acquire the information essential to an intelligent skepticism without relying on scientists. His answer, instead, is that regulators should respond with a bias of their own a bias that he claims to draw from public consensus, "a societal commitment to risk avoidance that might almost be said to be natural to a modern level of existence" (Nation, p. 141).

However, it is unclear that a social commitment of this sort exists. To be sure, people do expect that they will be protected from many risks. Shapo correctly perceives that scientific advances, in combination with the expanding role of government, have increased our expectations that we will be protected from many injuries and illnesses long regarded as inevitable. But it is too simple to ascribe the incurring of risks to callousness, greed, and insensitivity. Largely as a result of science's increased power to trace fine causal links, we have begun to realize that the most ordinary of activities (e.g., turning on a light) subjects other individuals to anticipated and unanticipated risks. It is difficult to maintain a sense of community, or shared obligation, when we are aware that our way of life necessarily entails risks to each other and to future generations. It is easier to ignore the problem than to recognize openly that we are, indeed, willing to sacrifice other lives to preserve our lifestyle.

Even if Shapo's "working principle" does reflect a consensus, I wonder whether it will help lawyers and scientists to reach reasoned decisions. As in Duty, Professor Shapo's guides for decision making are vague. Two examples:

Taking a somewhat resigned perspective on the previously established existence of the risk, [the Eighth Circuit decision in Reserve Mining Co. v. $E P A, 514$ F.2d 492 (8th Cir. 1975)] responds to the tensions created 
by conflicting interests that rend residents in the same community, at once maintaining the role of the judiciary as legislative interpreter as well as independent preserver of public health and safety. Inculcated in this approach is the idea that all law is a balance. Yet even in its recognition of competing interests, the decision teaches that in a "day of synthetic living," the basic line of the balance has shifted toward risk aversion because of the very artificiality of the processes that fuel that life-style. [Nation, p. 205.]

The central point is that ultimately both scientific conclusions and social decisions must be meshed into unified judgments. [Nation, p. 257.]

Shapo does draw on certain traditional legal doctrines, but they tend to end, rather than to further, discussion. For instance, Shapo's plea that risks not be incurred without full understanding and assent on the part of potential victims is derived from the tort doctrine of informed consent. But in Shapo's paradigm cases - where the most advanced scientific researchers only imperfectly understand the risks, where the potential victims are unidentified or unborn, or where the experts vigorously disagree - the doctrine of consent works, as Shapo acknowledges, as an absolute barrier because the necessary information cannot be communicated. In these situations, the doctrine of consent does not further choice. Instead, it bars action.

The other major doctrinal tool in Professor Shapo's arsenal is the placing of the burden of proof. He argues that the consensus supporting risk-averseness requires that we place the burden on those who would "experiment" with unconsenting citizens - that we exercise regulatory powers to elicit information on risks, and that we employ government power to avoid any risk of serious injury. Like the doctrine of consent, placement of the burden of proof ends discussion, for proof in the paradigm cases is, by definition, unavailable.

On the last day of its 1979 Term the Supreme Court of the United States decided a case challenging the adoption by the Occupational Safety and Health Administration (OSHA) of an approach quite similar to that advocated by Professor Shapo. ${ }^{9}$ OSHA had issued a standard placing stringent limitations on exposure to benzene. The Court described the agency's position as follows:

Whenever a carcinogen is involved, OSHA will presume that no safe level of exposure exists in the absence of clear proof establishing such a level and will accordingly set the exposure limit at the lowest level feasible. ... Given OSHA's cancer policy, it was in fact irrelevant whether there was any evidence at all of a leukemia risk [at the level set by the more lenient previous standard]. The important point [to OSHA] was that there was no evidence that there was not some risk,

9. Industrial Union Dept. v. American Petroleum Inst., 100 S. Ct. 2844 (1980). 
however small, at that level. ${ }^{10}$

The Supreme Court refused to read the Occupational Safety and Health Act of $1970^{11}$ to permit such a risk-averse approach. Instead, the Court read the Act to impose the burden of proof on OSHA. Under the Court's decision, before the government can issue a standard limiting exposure to a suspect substance, it must demonstrate that the proposed standard "is reasonably necessary and appropriate to remedy a significant risk of material health impairment." 12 The Court stressed that " 'safe' is not the equivalent of 'risk-free," "13 and refused to ascribe to Congress the "view that the mere possibility that some employee somewhere in the country may confront some risk of cancer is sufficient basis for the exercise of the Secretary's power to require the expenditure of hundreds of millions of dollars to minimize that risk." 14

In Nation, Shapo correctly points out that legal demands for proof of the sort imposed by the Supreme Court ask for a certainty that science cannot deliver. By hypothesis, in this area the burden of proof cannot be carried. To employ it as a decision making principle is to answer hard questions while pretending to defer to data collectors. The Supreme Court answers the question of indeterminable risks conclusively in favor of incurring the risk. But Shapo would employ the burden of proof in the opposite way, and his answer is just as conclusive. Shapo claims here, as he does in Duty, that his bias reflects a moral consensus. But this is not communication. It is fiat.

Nation, in contrast to Duty, pays more attention to the factors that destroy consensus, that make decision difficult. Professor Shapo acknowledges that significant groups in society urge expansion of scientific inquiry even when the costs of such inquiry are unknown, and that there is such a thing as overload of information about risks, an overload that could lead to "the kind of continuous personal deliberation that would occupy one's life exclusively with thoughts of physical hazard" (Nation, p. 141). And he is aware that a risk-averse perspective could well entail significant costs, both short-term (as the loss of industrial jobs) and long-term (as the loss of unsuspected benefits from basic research in genetics engineering.) However, he fails to account for these concerns adequately. At best he concedes that

\footnotetext{
10. $100 \mathrm{~S}$. Ct. at 2855 (emphasis original).

11. 29 U.S.C. $\$ \$ 651-678$ (1976).

12. $100 \mathrm{~S}$. Ct. at 2863 .

13. $100 \mathrm{~S}$. Ct. at 2864.

14. $100 \mathrm{~S}$. Ct. at 2869.
} 
they may be relevant to decision making. Although much of Nation consists of extended descriptions of regulatory action concerning particular scientific byproducts, Shapo suggests not legal rules, but, again, only "considerations" and "factors."

Much is attractive in Professor Shapo's enterprise. I admire his willingness to appeal to image and emotion in an effort to bring law in accord with lay expectations. But the weight to be given to image and emotion requires precise definition. Shapo asks lawyers to serve as facilitators of communication, but he has yet to master the very difficult problems of defining a shared morality and translating it into rules of decision. 